\title{
SOPRON TURISZTIKAI SZEZONALITÁSÁNAK ÉS A TURIZMUSFEJLESZTÉS SZÜKSÉGES IRÁNYAINAK VIZSGÁLATA
}

\author{
BARCZA ATTILA - CSAPÓ JÁNOS - HINEK MÁTYÁS - MARTON GERGELY \\ THE ANALYSIS OF TOURISM SEASONALITY AND \\ THE NECESSARY DIRECTIONS OF TOURISM DEVELOPMENT IN SOPRON
}

\begin{abstract}
Seasonality is one of the most characteristic features in the majority of the destinations basically depending on the natural and man-made attractions and their annual availability through the year. Based on this, one of the general objectives of tourism is to decrease seasonality where the attractions of the destination are managed in order to increase tourism consumption in the non-preferred periods as well. The main objective of the present study and research is to analyse the tourism seasonality of Sopron, one of the most important cultural tourism destinations of Hungary with the help of the GinI-index. This analysis reveals the impacts of earlier developments, on the one hand, and can also serve as a basis for the future developments pointing out the necessary areas of intervention, on the other.
\end{abstract}

Keywords: seasonality analysis, Sopron, tourism development, GinI-index

\section{Bevezetés}

A szezonalitás a desztinációk többsége esetében a turizmus egyik alapvető jellemzője, ami a természeti, illetve az ember alkotta vonzerők fogyasztók felé történő időbeli rendelkezésre állásának a függvénye (BARON, R. V. 1975). A témakör vizsgálata kapcsán megkülönböztethetünk egy- (pl. Balaton) és kétszezonú (pl. az Alpok) desztinációkat - amelyek esetében elő-, utó- és holtszezonok azonosíthatók az év során -, illetve ritka esetekben „szezonalitásmentes” célterületeket is (pl. Karib-térség).

A fentiekből adódóan a turizmusfejlesztés egyik általános célkitǔzése a szezonalitás mérséklése/csökkentése, aminek kapcsán a desztináció vonzerőit úgy menedzselik, hogy azok látogatása, igénybevétele a nem preferált időszakokban minél jobban közelítsen a kiemelt időszakok volumenéhez. E folyamat szélsőséges módszere a „four seasons” kínálat kialakítása, amikor ugyan nem túnik el teljesen a szezonalitás, azonban a holtszezon alapvetően kiküszöbölésre kerül (BUTLER, R. W. 1998, 2001).

A szezonalitás csökkentése érdekében kialakított beruházások és fejlesztések szakmai alapjait mindazon kvantitatív analízisek adhatják, amelyek egzakt módon képesek kimutatni az éven belüli turistaforgalom és az azt jellemző folyamatok eltérését. Ilyen módszerek a szezon paramétereiben az eloszlásfügg vények által azonosított matematikai aránytalanságok, hiszen azok a havi forgalom konkrét megoszlását azonosítják.

Jelen kutatás és tanulmány elsődleges célja Sopronnak, hazánk egyik kiemelkedő kulturális turisztikai desztinációjának a vizsgálata a szezonalitás szempontjából a Gini-index segítségével. A vizsgálat egyrészt feltárja a korábbi fejlesztések hatását a szezonalitás csökkentésére, aminek során elsődlegesen a 2016-tól datálható, intenzívebb fejlesztési időszakot tekinti át. Ezt az indokolja, hogy míg a Sopron határváros státuszából adódó turisztikai előnyök a rendszerváltást követően viszonylag hosszú ideig, mintegy 2010-ig érvényesültek kedvezően a vendégforgalmi adatokban, a város és térsége viszonylag kevés turizmusfejlesztést szolgáló forráshoz tudott csak jutni. A vizsgálat ezen túlmenően segítheti, meg- 
erősítheti azoknak a beavatkozási pontoknak a feltárását, azonosítását, amelyek a jövőbeli fejlesztések alapjául szolgálhatnak. A tanulmány és a kutatás további aktualitása, hogy az Nemzeti Turizmusfejlesztési Stratégia (NTS) által meghatározott, kiemelt turisztikai régiók egyikének, a Sopron-Fertő kiemelt turisztikai fejlesztési térségnek természetesen kiemelt szereplője Sopron. Továbbá az is erősíti a kutatás relevanciáját, hogy - felismerve a terület fontosságát - a Kisfaludy Turisztikai Fejlesztési Program desztinációs logikán alapuló termék- és attrakciófejlesztés, alapinfrastruktúra-fejlesztés pillére is hangsúlyosan emeli ki a térbeli és időbeli koncentráció oldásának fontosságát, lehetőségeit (NTS, 2030).

\section{Módszertan}

A Gini-együttható valamilyen gyakorisági eloszlás értékei közötti egyenlőtlenség mértékét méri. Az index alkalmazási lehetőségeinek szemléltetése kapcsán az eloszlást klasszikusan emberek, embercsoportok jövedelmeinek (pl. a populáció deciliseinek átlagjövedelme) vizsgálatával lehet szemléltetni. Amennyiben a Gini-együttható értéke nulla, ebben az esetben a gyakorisági eloszlás minden értéke azonos, azaz minden emberre (vagy decilisre) azonos jövedelem jut és teljes az egyenlőség. Ellenben, ha a Gini-együttható értéke 1, az egyenlőtlenség maximális, egyetlen emberre (decilisre) jut az összes jövedelem. Ennek megfelelően a Gini-index értéke annál magasabb, minél nagyobb az egyenlőtlenség (GINI, C. 1912).

Az index az egyenlőtlenséget reprezentáló Lorenz-görbe segítségével számítható ki (1.ábra). A Gini-index értéke az egyenlőség egyenese ( $45^{\circ}$-os egyenes) és a Lorenz-görbe által bezárt terület nagyságának $(\mathrm{A})$ aránya a teljes háromszög területének $(\mathrm{A}+\mathrm{B})$ nagy-

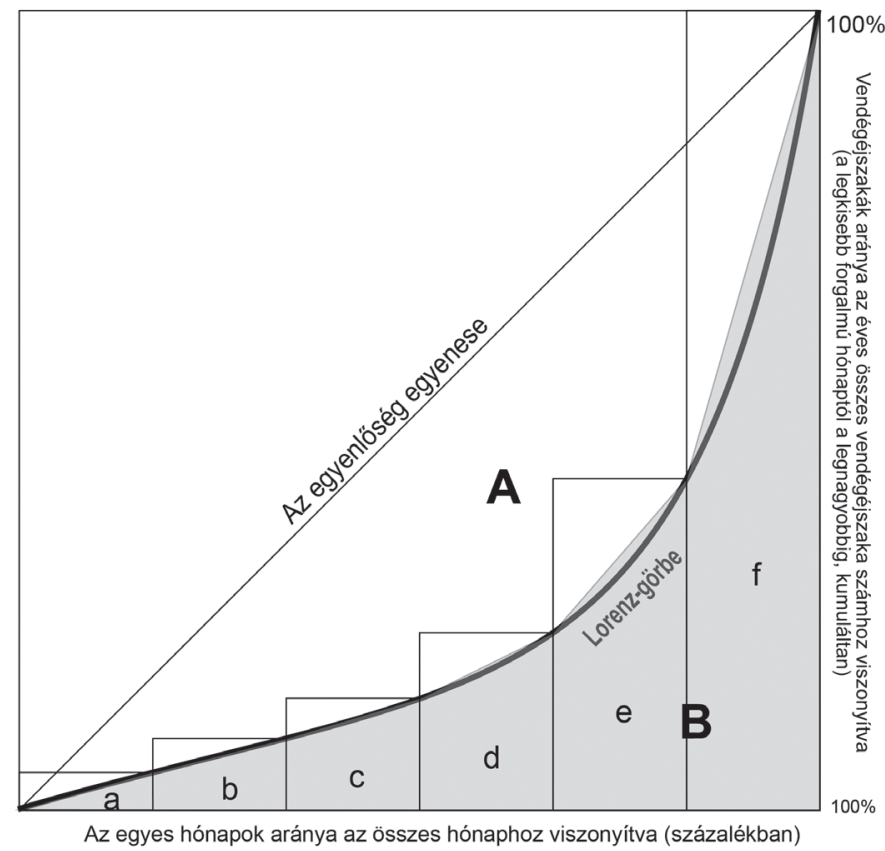

1. ábra A Lorenz-görbe alatti terület becslése trapezoidokkal, ha a gyakorisági változó diszkrét (pl. a vendégéjszakák száma, havonta). Forrás: KSH Tájékoztatási Adatbázis alapján saját szerkesztés

Figure 1 The estimation of the area under the Lorenz curve with trapezoids if the frequency variable is discrete (e.g. number of guest nights, monthly). Source: Authors' own editing based on CSO Hungary database 
ságához viszonyítva, konkrétan $\mathrm{G}=\mathrm{A} /(\mathrm{A}+\mathrm{B})$. Mivel az $\mathrm{A}+\mathrm{B}$ terület nagysága 0,5 , így $\mathrm{G}=\mathrm{A} / 0,5$, illetve $\mathrm{G}=2 \mathrm{~A}$, azaz az index nagysága a $45^{\circ}$-os egyenes és a Lorenz-görbe által bezárt terület (A) kétszerese.

Ha a vizsgált változó diszkrét - ahogy jelen esetben is a vendégéjszakák 12 hónapra bontott adatai -, a Lorenz-görbe alatti terület közelítő becsléssel, egyik oldalukkal a görbéhez illeszkedő trapezoidok területeinek összegeként adható meg. (A 'B' terület közelítő nagysága a szürke trapezoidok területeinek összege: $a+b+c+d+e+f$.)

A Gini-indexet széles körben alkalmazzák a turisztikai szezonalitás mérésére is, mivel kvantitatív módon reprezentálja a turistaforgalom szezonális egyenlőtlenségeit (FERNANDez-Morales, A. 2003; Fernandez-Morales, A.-Mayorga-Toledano, M. C. 2008; Bigovic, M. 2011; SulyoK J.-MESTER T. 2014).

A vendégéjszakák esetében a rendelkezésre álló adatok tükrében egy-egy év vendégforgalmi adatát havi bontásban (12 hónap) használjuk az elemzésben. A számítás során a következő formulát használjuk a Gini-index számítására (SUlYOK J.-MESTER T. 2014):

$$
G=1-\sum_{i=1}^{12}\left(X_{i}-X_{i-1}\right) \cdot\left(Y_{i}+Y_{i-1}\right)
$$

ahol:

$X_{i}$ - a hónapok kumulált részesedése az év 12 hónapjából;

$Y_{i}$ - a vendégéjszakák száma alapján növekvő sorrendbe állított hónapok kumulált vendégéjszakáinak részesedése az év összes vendégéjszakáiból.

\section{A szezonalitás kérdéskörének szakirodalmi áttekintése}

A szezonalitás mind a nemzetközi, mind a hazai turizmusban az egyik legfontosabb, célirányos, a turisztikai fejlesztésekkel csak részben befolyásolható tényező, amelynek komoly társadalmi, gazdasági és környezeti hatásai vannak. Természetesnek túnik tehát, hogy az 1960-as évektől, a tömegturizmus kialakulásával párhuzamosan a kutatók elkezdték vizsgálni annak szezonalitását is, hiszen kulcskérdés volt a turisztikai célú utazások időbeliségének alakulása, változása. A téma fontosságára elsők között BARON, R. V. (1975) hívta fel a figyelmet, akinek kezdeti publikációja óta számos turizmuskutató foglalkozott a témával, kollégái éppúgy, mint döntéshozók és iparági résztvevők (SUTCLIFFE, C. M. S.-Sinclair, T. 1980; Hartman, R. 1986; Donatos, G.-Zairis, P. 1991; Snepenger, D. et al. 1990; ButLer, R. W. 1994, 1998; LeE, C. et al. 2008).

BUtLER, R. W. (1994) véleménye szerint a szezonalitás a turizmus jelenségének tulajdonítható időszakos egyenlőtlenség, amely olyan elemekkel fejezhető ki, mint a vendégforgalom, a látogatók költése, az autópályák és egyéb közlekedési módok forgalma, a foglalkoztatás és a belépők számának alakulása. ALLCOCK, J. B. (1989) szerint ugyanakkor a fogalom úgy definiálható, hogy a szezonalitás az év egy rövid időszakában végbemenő koncentrált turistaáramlás, ami egyfajta fiziológiai jellemzője a turizmusnak.

A gazdasági szempontú megközelítésre alapozva TERRY, W. (2016) egy hosszabb időszak ciklikus fluktuációjaként értelmezi, míg FrECHLING, D. C. (2001) a gazdasági mutatók sorozatos változásaként értékeli a szezonalitást. MoORE, T. (1989) általános megközelítése úgy foglalja össze, hogy a ,szezonalitás az év egy különös időszakában végbemenő mozgások, amelyek minden évben visszatérnek". Kétségtelen, hogy sok kutató foglalkozott ezzel a faktorral, de a szezonalitásról viszonylag kevés alapos felmérés készült (BAUM, T.-HAGEN, L. 1999; BAum, T.-LundTORP, S. 2001). 
Éppen ez utóbbi az elmúlt évtizedek egyik legsikeresebb összefoglaló munkája, amelyben nemzetközi esettanulmányokkal illusztrálva, annak alapkérdéseiről, következményeiról, mérhetőségéról esett szó. A szerzők szerint a szezonalitás komplexitását jól érzékelteti, hogy az a kínálat elemeinek összességére van hatással, úgymint a marketingre (csomagok, árazás, elosztás), a munkaerópiacra (minőségi munkaeró, készségek, képzettség, valamint annak fenntarthatósága), a pénzügyre, az üzletre (készpénzállomány, árazás, beruházás vonzása), a tulajdonosi menedzsmentre (szállítók, közvetítók), valamint a múködtetés minden elemére. BUTLER, R. W. (2001) szerint az idény alakulásának lehetnek természeti - a klíma rendszeres változásai - és intézményesített okai, amelyek valamilyen szinten egymásra hatással bírnak. Az előbbi esetben az Egyenlítőtól való távolságnak van döntő szerepe, de vannak a trópusi övben is olyan területek, ahol egész éves turizmusról az extrém időjárási körülmények (hőség, szárazság, csapadék) miatt nem lehet beszélni. A klimatikus definiálást illetően HYLLEBERG, S. (1992) szerint „a szezonalitás szisztematikus, bár nem szükségszerúen rendszeres, éven belüli mozgás, amelyet az időjárás változása okoz”, mindemellett a klímaváltozás egyes desztinációkban további jelentős módosulásokat eredményezhet (AMENGUAL, A. et al. 2014).

Ami az intézményesített okokat illeti, azok a természeti tényezőknél sokrétúbbek is lehetnek, illetve részben jobban vagy pontosabban megjósolhatók, tervezhetők (pl. ünnepek, iskolai szünetek, hosszú hétvégék), hiszen azokat a kulturális, vallási, etnikai és társadalmi faktorok, a desztináció, a turisztikai termék vagy éppen a tevékenység népszerúsége egyaránt befolyásolják. BuTLER, R. W. (2001) szerint a szezonalitás leginkább problémaként jelenik meg a turizmusban, amit kezelni kell, bár bizonyos körülmények között (pl. távoli szezonális vidéki desztinációkban) az a foglalkoztatásban kedvező megoldást eredményezhet (FLOGNFELDT, T. 2001).

A HyLLEBERG, S. (1992) által szerkesztett kötet az időjáráson (hőmérséklet) kívül foglalkozik még a naptári hatással (ünnepek) és az időzítéssel (iskolai szünetek), mint a szezonalitás három legfontosabb okával. A kötet kiemeli továbbá, hogy ezek közül vannak stabil időpontok, ünnepek (Karácsony) és előfordulnak folyamatosan változók (Húsvét), illetve megjósolhatatlanok (időjárás).

Az intézményesített okok között említhetők a szokások, a tradíciók, a sportszezonok, így nem meglepó, hogy az idény jellegét vizsgálták a sport- (Higham, J.-Hinch, T. D. 2002) és a rekreációs tevékenységek (HARTMANN, R. 1986; BUTLER, R. W. 1994) szempontjából is. Hozzájuk is csatolható a szezonalitás negatív hatásának a megfogalmazása, miszerint a rekreáció és turizmus csúcsidőbeli egyenetlen eloszlása az egyik legmeggyőzőbb problémaként azonosítható, ami eredménytelen forráshasználatot, potenciális profitveszteséget, társadalmi, ökológiai kapacitásfeszültséget és adminisztratív nehézséget okoz (MANNING, R. E.-Powers, L. 1984). A periférián szereplő desztinációk esetében erőteljesebben jelenik meg a szezonalitás kérdése (BAUM, T.-HAGEN, L. 1999), ahol elsősorban a szezonhosszabbítás kérdéskörét vizsgálják (CANNAS, R. 2012). A szezonalitás jelentőségét az Eurostat (2016) adatai is megerósítik, ezek szerint az utazások száma tekintetében az európaiak minden negyedik turisztikai célú útja 2015-ben július-augusztusban történt, ha pedig azok hosszát vizsgáljuk, akkor még erőteljesebb a koncentráció.

A szerzők egy korábbi munkájukban kimutatták (MARTON G. et al. 2017), hogy magyar tudományos kutatások során az elmúlt évtizedekben - a Magyar Tudományos Múvek Tára alapján - mindössze 18 olyan publikáció született magyar nyelven, amelyek a turisztikai szezonalitás kérdéskörét vizsgálták, angol nyelven pedig az utóbbi években nem készült hazai kutatóktól e témakörben tudományos munka. A kutatások viszonylag csekély száma feltehetőleg a hazai desztinációk különbözőségére vezethető vissza, hiszen többségük egyszezonú, igen érzékeny turisztikai desztináció. Az idény-meghosszabbítás tehát igen sarkalatos pontja a hazai turisztikai fejlesztéseknek, beruházásoknak és az egész turiszti- 
kai ágazatnak, hiszen jelentősen befolyásol(hat)ja annak teljesítményét, bevételeit. Ennek a hiátusnak rövid áttekintésekor, a fentiekben már említett irányvonalaknak megfeleló területeken születtek publikációk. Ezek között volt a gasztronómiához, a termálfürdőkhöz, a hegyvidékekhez, a kereskedelmi szálláshelyekhez vagy éppen a turizmus egészéhez köthetố tudományos igényű publikáció is. Az elkészült munkákról elmondható, hogy a rendszerváltásig jellemző́en statisztikai jellegú tanulmányok jelentek meg, amelyek elsősorban gazdasági szektorokon átívelő kiigazítások módszertanát jelentették, turisztikai jellegük kevéssé volt megfogható (Herman S. 1985; Hrubos I.-PAIzs J. 1968). Egyedül a kereskedelmi szálláshelyek szezonalitását vizsgáló publikációk voltak azok, amelyek a klasszikus kínálati elemen keresztül elemezték a turisztikai szezont (HeRMAN S. 1987, 2000; SUGÁR A. 2000). Időrendben haladva a következő, a turizmus időszakosságát boncoló munka a termálturizmus szezonhosszabbításának lehetőségét értékelte (MARTON I. et al. 2001). Ezzel egy időben mélyült el a Magyar Turizmus Zrt. Piac- és Termékelemzési Irodáján az a kutatótevékenység, amely a hazai turisztikai szektor teljesítményéról is rendszeres felmérést végzett. Ezen belül készült el az ország turizmus-szezonalitását bemutató tanulmány (SULYOK J.-KISS K. 2006), majd később, erre is építve, kimondottan a kereskedelmi szálláshelyek vendégforgalmát vizsgáló felmérés (SULYOK J.-MESTER T. 2014).

A turisztikai termékek közül DÁvID L. és TóTH G. a Mátra esetében a hegyvidéki területek szintén szezont meghosszabbító lehetőségeit vették górcső alá, ahol nem megbízhatóan, de alkalmanként téli turizmusról is lehet beszélni (DÁvID L.-TótH G. 2009).

A fenti munkákhoz hasonlóan a gasztro- és a borturizmus szezonkiterjesztésének vizsgálata lett a központi téma, egy alkalommal étlaptervezés kapcsán (VÁGI Zs. 2012a, b), illetve a borfogyasztási szokások figyelembevételével (HARSÁNYI D.-Gálné CZÉKuS I. 2015). Ezt a folyamatot zárta le ugyanebben az évben egy gasztronómiai fesztivál turisztikai hatásainak és szezonalitásának bemutatása (NAGY G. Zs. 2015).

Összességében elmondható, hogy a - kis számú - hazai kutatások inkább termékközpontúak voltak, amelyek a kiválasztott témakört kívánták a szezonra gyakorolt hatások kapcsán bemutatni, így azok nem tekinthetők elméleti állásfoglalásoknak (MARTON G. et al. 2017).

\section{Sopron turizmusának és turizmusfejlesztésének meghatározó irányai}

Sopron turizmusának fejlődése a XX. századtól napjainkig több olyan idôszakot is tartalmazott, amely egymástól gyökeresen eltérő körülményeket, feltételeket és fejlesztési forrásokat biztosított a térség számára. A Vasfüggöny időszakának elszigeteltsége a határvárosi státuszt erősítette és a hatvanas években elsősorban a belföldi, egynapos turizmus fejlődését tette lehetővé. A hetvenes-nyolcvanas években, az enyhülés időszakában szintén a határváros jelleg (,a Nyugati kapu”) volt a meghatározó, amit az egyre növekvő beutazóturizmus és a nyugati irányú, adminisztratív korlátozások alá eső, de fejlődő magyar kiutazóturizmus, valamint az osztrák szolgáltatásturizmus, egészségturizmus, a magyar és osztrák bevásárlóturizmus jellemzett. Ez a jelenség a határhelyzetből eredően mintegy automatikus turistaforgalmat generált és Sopronnak kedvező pozíciót biztosított (Győr-Moson-Sopron... 2002, p. 313.).

Politikai-ideológiai okokra visszavezethetően (Vasfüggöny), ebben az időszakban a határtérség turisztikai célú fejlesztése nem volt cél, így forráshiány nehezítette a kínálati elemek fejlesztését. A rendszerváltás után, majd az EU-tagság megvalósulásával a határváros turisztikai jelentősége csökkent. A schengeni folyamat a határátlépési korlátozások feloldásával tovább gyorsította ezt a folyamatot, aminek során jelentős turisztikai szegmensvesztés következett be, ez a vendégforgalom alakulásában is megmutatkozott (KSH: Jelentés..., 2011 p. 45.). 2010-ig a határváros szerep különösebb turisztikai fejlesztések és 
marketingtevékenység nélkül is olyan vendégforgalmat generált, ami biztos helyet jelentett Sopronnak az ország 10 legnépszerűbb települése között.

A kedvező pozíció ellenére azonban a turizmus új hazai és nemzetközi trendjei, a hazai keresleti és kínálati piac változásai nyilvánvalóvá tették, hogy vitathatatlan turisztikai értékei ellenére Sopron további pozícióvesztésének megállításához jelentős forrásokra, fejlesztésekre és szemléletváltásra van szükség (EGYED K. 2014). Míg 2010-ben Sopron a 7. legnépszerübb magyar úti cél volt (451 449 vendégéjszakával, a belföldi vendégek körében a 4., a külföldiekében a 10. hellyel), 2018-ra a város a 15. helyre esett vissza (KSH: Helyzetkép..., 2018; KSH: Jelentés..., 2011. p. 45.).

A város tágabb térségére kitekintve, a 2001-ben a Fertő-táj Kultúrtáj Világörökség cím elnyerésével új turisztikai lehetőségek nyíltak. A Széchenyi Terv, a Nemzeti Fejlesztési Terv és az Új Magyarország Fejlesztési Terv által biztosított források jelentôsek voltak ugyan, de messze nem oldottak meg minden strukturális problémát, így a soproni TDM megalakulása, majd a 2015-2016-tól megindult fejlesztések jelzik azokat a lehetséges kitörési pontokat, amelyekkel Sopron és térsége újrapozícionálhatja magát a hazai és nemzetközi turisztikai piacon.

A város turizmusának és turizmusfejlesztésének legújabb aspektusát az határozta meg, hogy a kormány a 429/2016. (XII. 15.), a turisztikai térségek és a kiemelt turisztikai fejlesztési térségek meghatározásáról szóló rendeletében létrehozta a Sopron-Fertő kiemelt turisztikai fejlesztési térséget. A fejlesztési régió az alábbi települések által lehatárolt területet foglalja magába: Bük, Fertőboz, Fertőd, a Fertő-Hanság Nemzeti Park területe, Fertőhomok, Fertőrákos, Fertőszentmiklós, Fertőszéplak, Hegykő, Hidegség, Sarród (ideértve Fertóújlak települést is), Nagycenk, Röjtökmuzsaj, Sopron, Sopronhorpács és Zsira. E földrajzi lehatárolás a desztinációt egyedi és sokrétű adottságokkal rendelkező területté ruházza fel, komplex és egységes élménykínálattal. A régió alapvető kínálati elemeit az egészség-, a kulturális, az aktív és az ökoturizmus adja.

A térség egyértelmúen kiemelt, központi települése Sopron, amelynek idegenforgalma a kulturális (Sopron történelmi belvárosa, VOLT fesztivál) és egészségturizmuson (orvosi és szépészeti beavatkozások, a Lőverek klimatikus gyógyhelye, Sopron-Balf), illetve a gasztronómián (Soproni Borvidék) nyugszik.

A térség turizmusának legfontosabb és a nemzetközi desztinációvá váláshoz elengedhetetlen eleme a megközelíthetőség javítása, amely felismerés kapcsán 2018-ban hazai forrásból, közel 300 milliárd forint értékben kezdődött el egy kétsávos gyorsforgalmi út építése, amely a Sopron-Fertő kiemelt turisztikai térséget bekapcsolja a hazai és nemzetközi úthálózatba, $\mathrm{s}$ ezzel nagymértékben javítja a desztináció megközelíthetőségét, mind belföldi, mind nemzetközi tekintetben. Fontos megjegyezni, hogy ez a fejlesztés az alapja minden tervezett és folyamatban levő turisztikai fejlesztésnek és jelenti a jövőbeli stratégiai tervezés mérföldkövét.

A Sopron-Fertő kiemelt turisztikai fejlesztési térség meghatározásáról és a térségben megvalósítandó egyes fejlesztések megvalósításához szükséges források biztosításáról szóló 1862/2016. (XII. 27.) Kormányhatározat tételesen jeleníti meg a térségben európai uniós és hazai források bevonásával megvalósuló fejlesztések listáját, amelyek fő stratégiai fejlesztési irányait az alábbi területek adják:

- A térség turisztikai vonzerejének erősítése a gyógyhelyek (Sopron-Lőverek, SopronBalf, Bükfürdő), a világörökségi helyszínek, illetve az aktív turisztikai hálózatok fejlesztését, a nagycenki és fertődi kastélyok felújítását, továbbá a turisztikailag frekventált térségek integrált termék- és szolgáltatásfejlesztését foglalja magában (a megítélt támogatási összeg 10,1 milliárd forint).

- A soproni történelmi belváros, középkori várnegyed kulturális örökségvédelmi fejlesztése a Soproni Várfal, a Fabricius-ház, a Tábornokház és a Storno-ház turisztikai célú fejlesztését és Múzeumnegyeddé történő kialakítását, továbbá a Szent Mihály- 
templom és Sekrestyésház turisztikai célú fejlesztését irányozza elő (a megítélt támogatási összeg 10,3 milliárd forint).

- A Lőverek programban megújul a fedett uszoda a strandmedencével, kerékpárutak épülnek, kialakításra kerül a Lóver Alpin Park, illetve az 1200 fó befogadására alkalmas Nemzeti Konferenciaközpont, emellett további útfelújításokat fognak végezni (a megítélt támogatási összeg 16 milliárd forint).

- A Fertő tó turisztikai attraktivitásának fejlesztése, ami magába foglalja az alapinfrastruktúra fejlesztését, a vízminőség javítását, továbbá a vendégfogadás és szállásadás infrastruktúrájának megteremtését (a megítélt támogatási összeg 23,3 milliárd forint).

A kiemelt desztinációban létrejövő beruházások gyors és hatékony megvalósítására az állam létrehozta a 100\%-ban állami tulajdonban álló Sopron-Fertő Turisztikai Nonprofit Zrt.-t, amelynek feladata a 2022-ig tervezett, csaknem 60 milliárd forint összegú fejlesztések koordinálása. A fejlesztések vízi turizmushoz, egészségturizmushoz, aktív turizmushoz köthetô aspektusai azért is kiemelten fontosak, mert mind a hazai, mind a nemzetközi népszerű úti célok között a vízi attrakciókkal, fürdőturizmussal rendelkezők vezető pozíciójának folyamatos megerősödése látható, így a soproni uszoda, ill. a Fertő tavi Vízicentrum fejlesztése vélhetően ezt a kínálati szegmenst teremti meg Sopron számára. A nemzetközi szintû marketingtevékenység ellátására 400 millió forint támogatást kap a vállalkozás a Magyar Turisztikai Ügynökség költségvetéséből (1862/2016. (XII. 27.) Korm. határozat).

A 2008-as Integrált Városfejlesztési Stratégiában (IVS) meghatározott projektek közül különösen nagy jelentőségú „A városközpont értékmegőrző megújítása - I. ütem” elnevezésú program, amely 2009 és 2013 között közel 750 millió forint támogatást nyert el európai uniós társfinanszírozással. A program legfóbb elemei a Fó tér és a Túztorony felújítása, a Várfalsétány, valamint az Információs és Fogadóközpont kialakítása voltak.

2016-ban Magyarország Kormánya a Modern Városok Program keretében 1,98 milliárd forint támogatást nyújtott Sopronnak, annak érdekében, hogy a korábban megkezdett értékmegőrző megújítások folytatódjanak. Ezt 2018-ban és 2019-ben is hasonló léptékű hazai források egészítik ki.

A közterek kedvező szerkezetére és sajátos történelmi hangulatára alapozott turisztikai programok, a város rendezvénykínálata, illetve a történelmi kisváros építészeti és további kulturális értékei ellenére azonban Sopron Magyarország 25 leglátogatottabb vidéki városa közül 2018-ra „csak” a 15. helyet foglalta el (a belföldi vendégek körében a 11., a külföldiekében a 17. hellyel), amiben természetesen jelentős szerepet játszik a nevesebb fürdővárosaink hagyományosan magas látogatottsága is. Számszerúsítve ez a pozíció 2018-ban 381082 vendégéjszakát jelentett, ebből - főként a nyugati határ menti helyzete miatt - nagy arányban részesednek a külföldi látogatók, elsősorban Németországból és Ausztriából (KSH: Helyzetkép..., 2018. p. 15., p. 26.).

2017-hez képest ez az érték összességében 1,3\%-os növekedést, azon belül a belföldi vendégek esetében 6,7\%-os bővülést, viszont a külföldiek vonatkozásában 14,7\%-os csökkenést jelent. A látogatások száma ugyanakkor az utóbbi évek tendenciáját tekintve csökkent, amiben a nagy volumenú felújítási munkálatok és egy-két nagyobb kapacitású szálláshely bezárása is szerepet játszhatott (Sopronban a kereskedelmi szálláshelyeken eltöltött, regisztrált vendégéjszakák döntő többsége a szállodákban realizálódik). A turisták átlagos tartózkodási ideje a városban alig 2,4 nap.

Egy korábbi kutatás alapján, amely a tér és környezet transzformációs hatásait vizsgálta Sopron példáján keresztül (Aubert A.-BArCZA A.-PÁlfi A.-MAgYAR-PAPP J. 2017), meghatározhatjuk, hogy az ideérkező turisták által felkeresett attrakciók nagyobb területi kiterjedést mutatnak, amit magyaráz a Fertő-táj Világörökségi terület és a Fertő tó, mint vonzerő közelsége és egy turisztikai termékként való piacra vitele. A kutatás alapján 
a TOP 5 felkeresett látnivaló a Történelmi Belváros, a Tűztorony, a Lőverek, a Fertő-part és a szakrális emlékhelyek.

A Sopronba érkező turisták számára az utazás fő motivációi a városlátogatás (a megkérdezettek 41\%-a) és a pihenés (31,9\%) (BARCZA A. 2014). A szúk értelemben vett centrumterület teljes körű megújításának igényét az is erősíti, hogy ugyanezen felmérés során a felkeresett vagy felkeresni tervezett fő turisztikai attrakciók közül a válaszadók a történelmi belváros megtekintését említették a legmagasabb arányban (86,9\%).

A fentiek alapján elmondható, hogy Sopronban az elkövetkező időszakban olyan kiemelkedő turisztikai és infrastrukturális beruházások allokációjára kerül sor, amelyek a települési megújulás eredményeként a közeljövőben egy koherensen fejlődő, egységes arculatú, a nemzetközi turisztikai versenyben is helytállni képes várossá tehetik.

\section{A Gini-együttható meghatározása és értékelése Sopron turizmusának tükrében}

Az elmúlt 18 évben Sopron szezonalitása enyhén csökkent. Míg 2000-ben a Gini-index értéke az országos átlag alatt, 0,202 volt, 2016-ra 0,163-ra csökkent. A csökkenés azonban nem volt egyenletes, a vizsgált csaknem két évtizedben például előfordultak olyan évek is, amikor a szezonalitás nőtt a város kereskedelmi szálláshelyein. Ilyen volt egyebek mellett a 2001-2005 közötti időszak, aminek végére a Gini-index elérte a vizsgált periódus legmagasabb értékét $(0,236)$, de ilyen volt a gazdasági-pénzügyi válság induló éve (2008) és emelkedett a szezonalitás 2011 és 2013 között is. 2013-ban a növekedés több mint 35\%-os volt, ez a vizsgált időszak legnagyobb emelkedése.

Ugyanakkor a vizsgált évek többségében a szezonalitás mérséklődése volt jellemző. A legnagyobb csökkenés az előzó évhez viszonyítva 2011-ben, illetve 2016-ban volt megfigyelhetó $(-27,1 \%$ és $-19,1 \%)$, de a $2006-$ os $-17,8 \%$ is nagyobb csökkenés, mint az azt megelőző és következő években. Az index kettővel több évben csökkent, mint nőtt (10 vs. 8 év), illetve a csökkenések összesített értéke meghaladta a növekedések összesített értékét. Ezt a 18 év adataira illesztett lineáris trend is jelzi, eszerint a Gini-index csökkenése évente átlagosan 0,0015 volt (2.ábra).

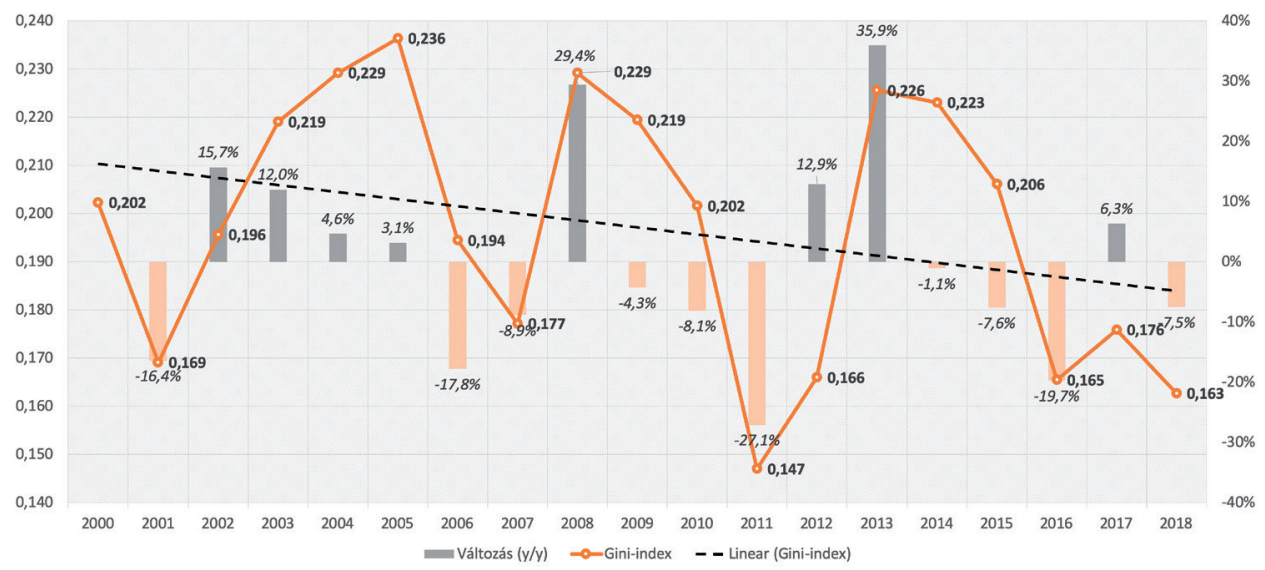

2. ábra Sopron vendégéjszakáinak Gini-indexe, 2000-2018. Forrás: KSH Tájékoztatási Adatbázis alapján saját szerkesztés Figure 2 The Gini index of the guest nights of Sopron, 2000-2018. Source: Authors' own editing based on CSO Hungary database 
A szezonalitás alakulását érdemes összevetni a soproni kapacitások alakulásával, különös tekintettel arra, hogy ebben az időszakban a kereskedelmi szálláshelyek szobáinak száma 31\%-kal, a kiadható férőhelyek több mint 20\%-kal nőttek országosan. Sopronban a szállásféróhelyek száma a 2000. évi 5,5 ezerról 2018-ra 2,8 ezerre, a kiadható szobák száma 1,6 ezerről 1,1 ezerre, a múködő kereskedelmi szálláshely egységek száma 50-ről 35-re csökkent, azaz a kapacitások több mint 30\%-os visszaesése figyelhető meg, ami az országos tendenciákkal ellentétes (3.ábra). A jelenség Sopron határváros helyzetével van összefüggésben, valamint a város életében meghatározó csökkenést eredményezett két szálloda (Hotel Maroni, Hotel Fagus) bezárása is.

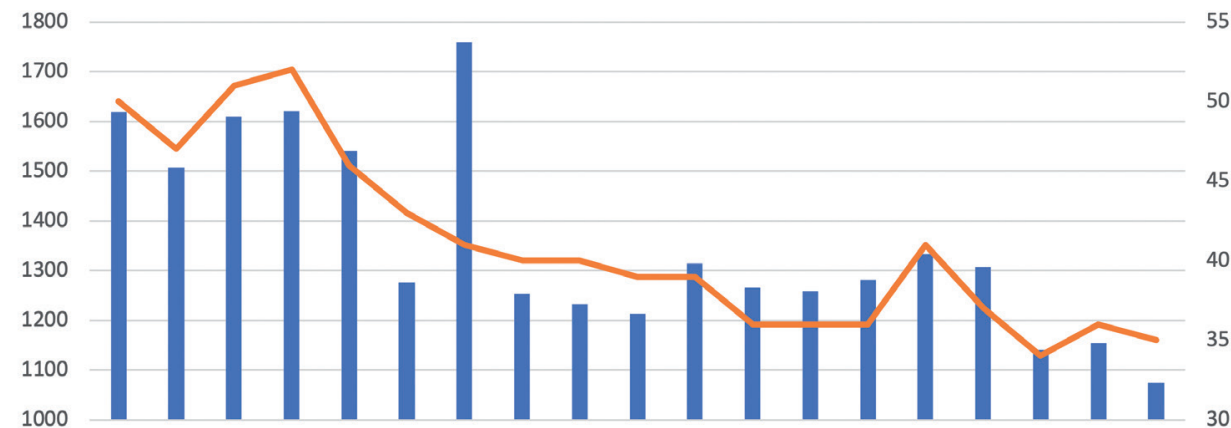

2000200120022003200420052006200720082009201020112012201320142015201620172018

Kiadható szobák száma (db) (bal tengely)

Múködő kereskedelmi szálláshely egységek száma (db) (jobb tengely)

3. ábra Múködő kereskedelmi szálláshelyek és kiadható szobák, Sopron, 2000-2018 Forrás: KSH Tájékoztatási Adatbázis alapján saját szerkesztés.

Figure 3 The functioning commercial accommodations and their bed places, Sopron, 2000-2018 Source: Authors' own editing based on CSO Hungary database

A szezonalitás és kapacitások mellett érdemes megvizsgálni, a soproni vendégforgalmi adatokat is. A vizsgált időszak elejét és végét összehasonlítva, a vendégéjszakák száma a 2001. évi 385 ezerről 2018-ra enyhén, 379 ezerre csökkent. Az időszak két csúcséve 2010 és 2011 volt, közel 440 ezer, illetve 450 ezer vendégéjszakával, de az ezt követő években jelentősen visszaesett és az elmúlt években 364 ezer és 379 ezer között ingadozott. Ugyanez figyelhető meg a vendégek száma tekintetében is: a 2001. évi 154 ezerrel szemben 2018-ban gyakorlatilag változatlan, 157 ezer volt a kereskedelmi szálláshelyeken regisztrált vendégek száma. Noha a vizsgált időszak közepén, 2010-2011-ben több mint 180 ezer vendég töltött el legalább egy vendégéjszakát Sopronban, ám az ezt követó években a vendégek száma visszaesett, majd stagnált. Sopron vendégforgalma tehát az elmúlt közel két évtizedben nem az országos trendeket követte. Miközben országosan, ingadozásokkal ugyan, de nőtt, addig a városban az ingadozásokat leszámítva nem változott érdemben a kereskedelmi szálláshelyeken regisztrált vendégek és vendégéjszakák száma (4. ábra).

A szálláshelyek és a kiadható szobák számának csökkenése (3.ábra), ami ellentétes az országos tendenciákkal, a belső migráció növekedésének kísérőjelensége lehet. A városban és környékén több ezerre tehető azoknak a magyar munkavállalóknak száma, akik Sopronban vagy környékén bérelnek lakást, szobát és naponta ingáznak ausztriai munkahelyükre. A szállásadók viszonylag könnyen találnak hosszú távra, megfelelő fizetőképességú bérlőket, amivel szálláshelyük szezonalitása csökkenthető. A városban nagy a kereslet kiadó lakások, szobák iránt, ezért vélhetóen a kiadó szálláshelyek száma azért 


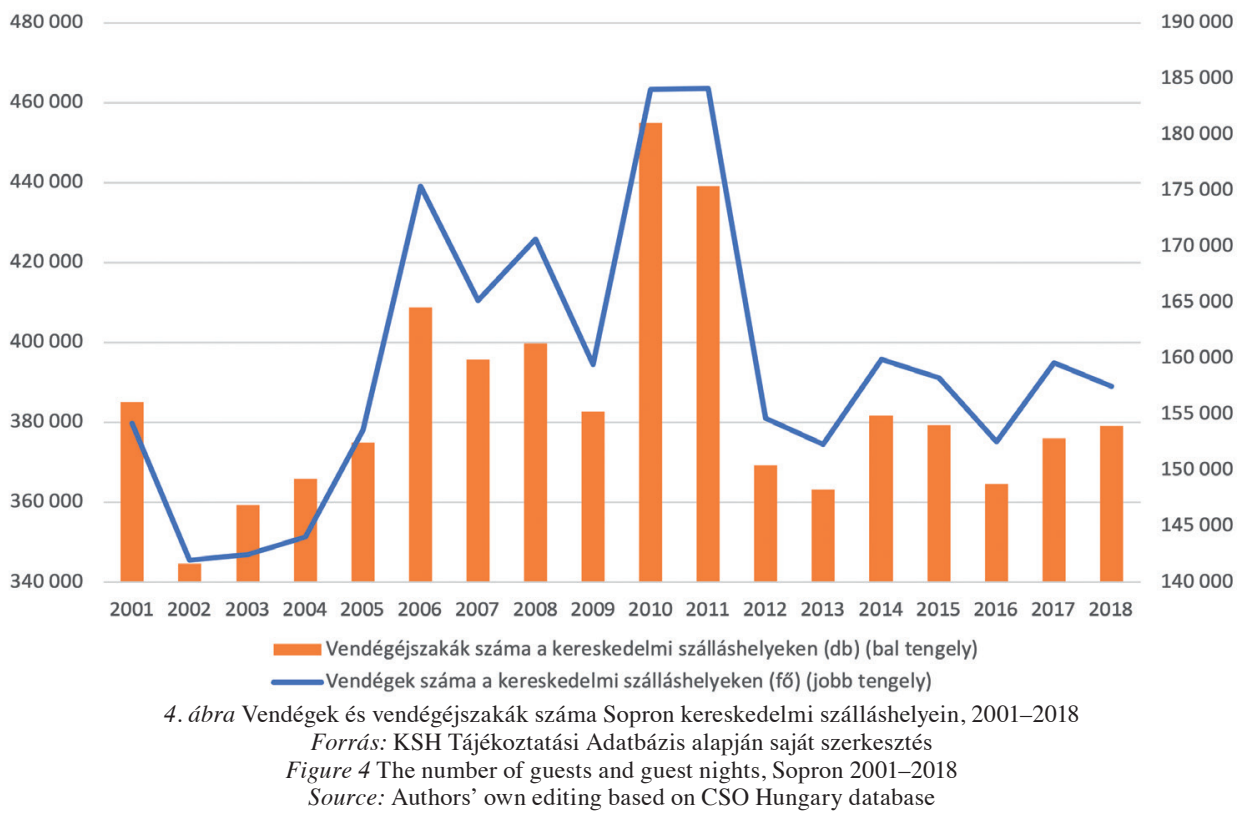

is csökkenhetett, mert a szállásadók a turisztikai célú hasznosítás helyett a hosszú távú bérbeadás mellett döntöttek.

A vendégéjszakák számának alakulása csökkenő-stagnáló tendenciát mutat. A 2012-2018 közötti időszak adatai azt jelzik, hogy Sopronnak még nem sikerült megtalálnia új turisztikai szerepkörét, illetve egy olyan desztinációt megjeleníteni a kínálati piacon, amellyel a csökkenő-stagnáló vendégszám növelhető lenne. Vannak olyan rendezvények, amelyek a város imázsát kedvezően alakítják (pl. a VOLT Fesztivál) és a város ismertségére, népszerüségére kedvező hatással vannak. A VOLT nemzetközi ismertségének növekedése és látogatószámának emelkedése azt jelzi, hogy egy-egy ilyen zenei rendezvény is jól beilleszthetô a klasszikus turisztikai értékek mellett a kínálatba. A vendégszám jelentős növekedését jelzi, hogy a fesztivál 1993. évi első rendezvényén 800 fő vett részt, 2010-ben már 79 ezer, a 2017-es rekordévben 160 ezer, 2019-ben pedig 143 ezer volt a látogatók száma. A kapacitásadatokból következik, hogy egy ilyen nagyrendezvény szállásigényét csak térségi szinten tudják kielégíteni.

A vendégszám kedvezőtlenebb alakulását részben befolyásolja az osztrák határtérség intenzív marketingje, csomagajánlatai (Neusiedler See Card) és változatos élményturisztikai kínálata (Familypark - St. Margarethen, St. Martins Therme - Frauenkirche, Sonnentherme - Lutzmannsburg-Frankenau). Ez egyre több magyar vendéget vonz, akik gyakran Sopronban vagy környékén, illetve a kevésbé árérzékeny vendégek Ausztriában foglalnak szállást (EGYED K. 2017). A turisztikai trendek azt valószínúsítik, hogy az élményturisztikai elemek, a vízi és fürdőturisztikai attrakciók, a turisztikai szegmensekre kidolgozott csomagajánlatok a versenyképesség, a vonzerő, a vendégforgalom növelésének mind fontosabb tényezői lehetnek, mindezeket Sopron esetében még fejleszteni szükséges.

Elemzésünkben mindenképp foglalkoznunk kell a klasszikus turisztikai statisztikában meg nem jelenő - noha Sopron esetében az 1970-es évektől tartósnak tekinthető - szegmens, az egynapos látogatók, a bevásárlóturisták, a szolgáltató turizmust igénybe vevők nagy számával. A döntő többségében osztrák látogatók által reprezentált célcsoport elsődleges motivációja az egészségturizmus, ezen belül a fogászati turizmus. 
Sopronban, a „fogorvosok fóvárosában”, a kamarai nyilvántartások szerint mintegy 250-300 fogorvos dolgozik, akiknek zöme nem egész héten, hanem megosztott munkarendben rendel. Az egészségturizmuson belül egyre többen vesznek igénybe egészségmegőrző vagy állapotjavító szolgáltatásokat (masszázs, kúrák, szépészeti és gyógyászati beavatkozások) is. A szolgáltatásturizmus kiterjed a fodrászati, kozmetikai szolgáltatásokra, de egyre többen veszik igénybe az autószervizek, illetve más szakemberek szolgáltatásait is. Bükfürdó és Hegykő szállóvendégei közül szintén többen keresik fel látogatóként a várost.

A kiutazó magyar turistákra vonatkozó statisztikai idősor nem tartalmazza az 1988-ban a világútlevél bevezetését követő időszak tömeges, egynapos magyar „Gorenje-turistáinak” több tízezres sokaságát sem, akiknek egy része abban az időszakban egynapos szállóvendégként megjelent a soproni szálláshelyeken, ami kedvező pozíciót jelentett Sopron számára.

\section{Összefoglalás}

A kutatás Sopron turizmusát a turisztikai szezonalitás alakulása szempontjából vizsgálta a Gini-index felhasználásával E módszerrel kvantitatív módon tárhatók fel a turistaforgalom szezonális egyenlőtlenségei. A 2000-2018-as időszakot feldolgozó adatok alapján elmondható: annak ellenére, hogy Sopron turisztikai pozíciója a hazai népszerú úti célok között gyengült és mind a vendégforgalom, mind a szálláshelyi kapacitások tekintetében visszaesés következett be, a város vendégforgalmának szezonalitása kismértékben javult.

Sopronban a szezonalitás alacsonyabb, mint az országos átlag, aminek oka összetett. A kedvező hatás kevéssé a tudatos fejlesztés eredménye, inkább egyrészt a térségi kínálat összetétele, másrészt az osztrák kínálati elemek és vonzerők támogatják. A város turisztikai szezonalitását jelző Gini-index az elmúlt közel két évtizedben enyhén ingadozott, de ez nem köthetô egyértelmúen a gazdasági ciklusokhoz, például a 2009-ben kirobbant gazdasági válság hatásához. Jelezheti viszont azt, hogy a pozíciók még javíthatók. A szezonalitás nagyon enyhén csökkent, amiben közrejátszhat a belső migrációnak a szálláshelyek kapacitására gyakorolt hatása.

A vendégforgalom csökkenése ugyancsak összetett hatásrendszert feltételez, mert miközben a térségi kínálatában nagyléptékû fejlesztések zajlottak/zajlanak (fertődi Esterházykastély, Világörökség státus) országosan és regionális szinten a versenytárs városok (Győr, Bükfürdő, Sárvár, Zalakaros) termékfejlesztése (elsősorban fürdőturizmus) is jelentős forráshoz jutott. Sopron a TOP 20 -as lista gyakorlatilag egyetlen termál- vagy élményfürdő nélküli települése.

Az adatok alapján az a következtetés adódik, hogy azok a turisztikai kínálati elemek, adottságok, többek között a határvárosi státus és programok, amelyek több évtizeden keresztül megfelelő turistaforgalmat és vendégszámot generáltak, a jelen körülményei között már kevéssé hatékonyak. A modern desztináció kialakítása és megfelelő marketingfejlesztés az új turisztikai státus formálásának meghatározó tényezői lehetnek.

A népszerú úti célokkal rendelkező városok rangsorában az a tendencia tükröződik, hogy a vendégforgalom növeléséhez, de akár megtartásához is alapvetően szükség van fürdőturisztikai és/vagy vízi turisztikai kínálati elemekre, termékfejlesztésre és az élményturisztikai beruházások forgalomnövelő hatása viszonylag rövid távon is megmutatkozik. Sopronban a korábbi időszakok fejlesztései ezt a területet nem érintették, viszont a közelmúlt gyógyturisztikai fejlesztései vélhetően kedvező hatást gyakorolnak a szezonalitásra. Sopron kereskedelmi szálláshelyei közül a vendégforgalom nagyobb hányadát lefedő hotelek, magasabb színvonalú szálláshelyek rendelkeznek ugyan wellness- és fürdôturisztikai kínálattal, azok kapacitása viszont saját vendégkörükre és nem város szintú 
vendégforgalomra méretezett. A jelenleg zajló fejlesztések érintik a városban levő uszodát és élményturisztikai elemeket is tartalmaznak, a nagyobb léptékű fejlesztés viszont a Fertő tavat érinti, amely nem közvetlenül Sopron területén található. Az osztrák térség fejlődését figyelembe véve, mindkét fejlesztés közvetett és közvetlen hatást is gyakorolhat mind a vendégforgalom növekedésére, mind a szezonalitás mérséklődésére. Nem egyértelmú viszont, hogy a Fertő tavi fejlesztés meghozza-e azt az áttörést és forgalomnövekedést Sopron turizmusában, mint amit egy helyben levő fürdőkomplexum jelenthetne.

A szálláshely-kapacitás csökkenése vonatkozásában egyrészt a modernizálás szükségessége és forrásigénye nevezhető meg, amihez nagyobb mérvú pályázati támogatások az elmúlt években lettek hozzáférhetők. Befolyásoló tényező ezen kívül a belső migráció ugrásszerú változása, ami az Ausztriába ingázó magyar munkaerő szállásigényének megnövekedését eredményezte. A szállásadók egy része a turisztikai hasznosítás helyett a teljes szezonalitást biztosító lakás- és szoba-bérbeadás mellett döntött, ami az osztrák bérszínvonal miatt megfelelő jövedelmezőséget és viszonylag megbízható bérlőket jelenthet. A befektetők számára a további fejlesztésekhez a szezonalitás mérséklésére is koncentráló desztináció-fejlesztés jelenthet ösztönzést.

Sopron határváros jellegéből következik, hogy a jelenleg zajló autópálya- és közútfejlesztések fokozott jelentôséggel bírnak, mert a meglévő úthálózat kapacitása már a Sopronba irányuló, ill. más úti céllal beutazó turistaforgalmon kívül a naponta többezres ingázó zökkenőmentes áteresztésére már nem képes. Az úthálózat fejlesztése ezért hangsúlyos tényező mind a térségi, mind a hazai turizmus számára.

A város természeti és kulturális adottságai kedvezőek a szezonalitás mérsékléséhez, de további élményturisztikai fejlesztések, az idegenforgalom szereplői közötti hálózatosodás és az intenzív és hatékony marketing jelentheti azokat a további tényezőket, amelyek a térséget az idegenforgalmi beruházók és a turisták számára is egész évben vonzó célponttá tehetik.

A vendégforgalmi adatok alapján Sopron turizmusa, elsősorban a kínálat dinamizálásának a hiánya, illetve az élményközpontú beruházások elmaradása miatt, közel egy évtizede stagnál, azonban a kínálati és keresleti mutatók volumene nem tekinthetô alacsonynak, így az megfelelő alapot képes szolgáltatni a jövőbeli beruházásoknak.

Mindezekkel párhuzamosan a kereskedelmi szálláshelyek száma és kapacitása jelentősen visszaesett, ami két fő okra vezethető vissza: egyrészt minőségi előrelépés történt az egységek modernizációja révén, másrészt a piac e része jelentős letisztuláson ment keresztül, emiatt az alacsonyabb minőségű szálláshelyek bezárásra vagy funkcióváltásra kényszerültek. A város szezonalitása lassan, de trendszerúen javult, ami szintén megfelelő alapot jelent a fejlesztések számára, hiszen ezáltal jól kirajzolódik, hogy az év nagyobb részében képes kiszolgálni a turisták igényeit.

A tanulmányban bemutatott, a turizmust érintő fejlesztések mindenképp szükségesek Sopron idegenforgalmának dinamizálásához, azonban a további volumennövekedés elérése érdekében a városnak ezeken túl további komplex, élményalapú beruházásokra van szüksége.

BARCZA ATTILA

PTE TTK Földtudományok Doktori Iskola, Pécs

barcza.attila@sopron.hu

CSAPÓ JÁNOS

PTE KTK Marketing és Turizmus Intézet, Pécs

csapo.janos@ktk.pte.hu 


\title{
HineK MÁTYÁs
}

Budapesti Metropolitan Egyetem, Turizmus és Marketing Intézet, Budapest mhinek@metropolitan.hu

\author{
Marton Gergely \\ PTE TTK Sporttudományi és Testnevelési Intézet, Pécs \\ martongergely@gamma.ttk.pte.hu
}

\section{IRODALOM}

Allcock, J. B. 1989: Seasonality. - In: Witt, S. F.-Moutinho, L. (ed.): Tourism Marketing and Management Handbook. Prentice Hall, Cambridge.

Amengual, A.-Homar, V.-Romero, R.-Ramis, C.-Alonso, S. 2014: Projections for the $21^{\text {st }}$ century of the climate potential for beach-based tourism in the Mediterranean. - International Journal of Climatology 34. pp. 3481-3498.

Aubert A.-Barcza A.-PÁlfi A.-Magyar-Papp J. 2017: A tér és a környezet transzformációs hatásainak vizsgálata Pécs és Sopron példáján, In: RÉGi T.-RÁtz T.-Michalkó G. (szerk.): Turizmus és transzformáció. 297 p.

BARCZA A. 2014: Vendégelégedettség kutatás Sopron város turistái körében. - Sopron Régió Turisztikai Központ Nonprofit Kft.

BARON, R. V. 1975: Seasonality in Tourism. A Guide to the Analysis of Seasonality and Trends for Policy Making. - London: The Economist Intelligence Unit Ltd., Technical Series N. 2.

BAUM, T.-HAGEN, L. 1999: Responses to Seasonality: the Experiences of Peripheral Destinations. - International Journal of Tourism Research vol. 1. pp. 299-312.

BAum, T.-LundTORP, S. 2001: Seasonality in Tourism. - Pergamon, Oxford, UK. 189 p.

Bigovic, M. 2011: Quantifying seasonality in tourism: a case study of Montenegro. Academica Turistica 4. 2. pp. $15-32$.

ButLER, R. W. 1994: Seasonality in tourism: Issues and implications. - The Tourist Review. International Association of Scientific Experts in Tourism 3.

ButLER, R. W. 1998: Seasonality in tourism: Issues and problems. - In: SEATON, A. V. (ed.) Tourism: State of the Art. Chichester, UK: Wiley. pp. 334-339.

ButLER, R. W. 2001: Seasonality in Tourism: Issues and Implications. - In: BAuM, T. - LundTORP, S. 2001: Seasonality in Tourism. Pergamon. Oxford, UK. pp. 5-23.

Cannas, R. 2012: An Overview of Tourism Seasonality: Key Concepts and Policies. - AlmaTourism. 5.pp. 40-58.

DÁVID L.-TóTH G. 2009: Hegyvidéki területek szezonalitásának problémái a Mátravidék példáján. - Földrajzi Közlemények 133. 1. pp. 33-41.

DonAtos, G.-ZAIRIs, P. 1991: Seasonality of foreign tourism on the Greek Island of Crete.-Annals of Tourism Research 18. 3.pp. 515-519.

EGYED K. 2014: Gondolatok a soproni régió turisztikai versenyképességéról. Soproni Szemle 68. 4.pp. 407-418.

EgYed K. 2017: A turisztikai ágazat fejlődése, In: JANKó F.-FÁBIÁN A.-HARDI T. (szerk.) Burgenland. Nemzetstratégiai Kutatóintézet pp. 353-384.

Eurostat 2016: Seasonality in tourism demand. Eurostat Statistics Explained. (Utoljára letöltve: 2016. október 9.)

FernandeZ-Morales, A. 2003: Decomposing Seasonal Concentration. - Annals of Tourism Research 30. 4. pp. 942-956.

Fernandez-Morales, A.-Mayorga-Toledano, M. C. 2008: Seasonal concentration of the hotel demand in Costa del Sol: A decomposition by nationalities. - Tourism Management 29. pp. 940-949.

Flognfeldt, T. 2001: Long-Term Positive Adjustments to Seasonality: Consequences of Summer Tourism in the Jotunheimen Area, Norway. - In: BAum, T.-Lundtorp, S. (ed.): Seasonality in Tourism. Pergamon. Oxford, UK. pp. 109-119.

Frechling, D. C. 2001: Forecasting Tourism Demand: Methods and Strategies. - Oxford: Butterworth-Heinemann.

Gini, C. 1912: Variabilità e mutabilità. - Reprinted in Pizetti, E.-Salvemini, T. (ed.) (1955): Memorie di metodologica statistica. - Rome: Libreria Eredi Virgilio Veschi.

Győr-Moson-Sopron Megye, Statisztikai Évkönyv, 2002. - KSH. p. 313.

HARSÁNYi D.-GÁLNÉ CzÉKuS I. 2015: Szezonális különbségek a borfogyasztási szokásokban. - In: SolT K. (szerk.): Alkalmazott tudományok II. fóruma: Konferenciakötet. Budapest: Budapesti Gazdasági Főiskola, pp. 238-246. 
Hartmann, R. 1986: Tourism, seasonality and social change. - Leisure Studies 5. 1. pp. 25-33.

Herman S. 1985: A szezonalitás vizsgálat statisztikai módszerei. - IGK Prodinform, Budapest. 4, 122 p.

HERMAN S. 1987: A kereskedelmi szálláshelyek vendégforgalmában mutatkozó szezonalitás tendenciáinak területi elemzése. - In: Területi Statisztika: 1987/4-5-6. szám. KSH Budapest., pp. 173-185.

HERMAN S. 2000: A szezonalitásból eredő kapacitás-kihasználatlanság területi összehasonlító elemzése. - In: SZTE GTK Évkönyve. Szeged. Szegedi Tudományegyetem. pp. 1-14.

Higham, J.-Hinch, T. D. 2002: Tourism, sport and seasons: the challenges and potential of overcoming seasonality in the sport and tourism sectors. - Tourism Management 23. 2. pp. 175-185.

Hrubos I.-PAizs J. 1968: Szezonális kiigazítási eljárások összehasonlítása. - KSH, Budapest. 188 p.

Hylleberg, S. (ed.) 1992: Modelling Seasonality. - Oxford University Press, New York, USA.

KSH: Helyzetkép a turizmus, vendéglátás ágazatról, 2018. p. 15, p. 26, statinfo.ksh.hu

KSH: Jelentés a turizmus 2010. évi teljesítményéről, 2011. p. 45. http://www.ksh.hu/docs/hun/xftp/idoszaki/jeltur/jeltur10.pdf

Lee, C.-Bergin-Seers, S.-Galloway, G.-O'marhony, B.-McMurray, A. 2008: Seasonality in the Tourism Industry: Impacts and Strategies. - CRC Sustainable Tourism Pty Ltd. Australia. 36 p.

Magyar Turisztikai Ügynökség, 2017: Nemzeti Turizmusfejlesztési Stratégia, 2030. https://www.kormany.hu/ download/8/19/31000/mtu_kiadvany_EPUB_297x210mm\%20-\%20preview.pdf

Manning, R. E.-Powers, L. 1984: Peak and Off Use: Redistributing the Outdoor Recreation/Tourism Load. - Journal of Travel Research 23. 2. pp. 25-31.

Marton G.-CsAPó J.-HineK M.-Kiss R. 2017: Pécs turizmusának vizsgálata a turisztikai szezonalitás tükrében a Gini-index segítségével. - In: Területfejlesztés és Innováció 11. 1. pp. 3-11.

Marton I.-SARudi Cs.-Nyáriné Budvig A. 2001: A termálturizmus a szezonhosszabbítás szolgálatában. - In: PALKOVICs M.-Kondorosiné VARGA E. (szerk.): „Vidékfejlesztés - környezetgazdálkodás - mezőgazdaság” 43. Georgikon Napok tudományos konferencia kiadványa. Veszprémi Egyetem Georgikon Mezőgazdaságtudományi Kar. 108 p.

MoORE, T. 1989: Handbook of business forecasting. - Harper and Row, New York.

NADAl, J. R.-FonT A. R.-Rosello, A. S. 2004: The economic Determinants of seasonal patterns. - Annals of Tourism Research 31. 3. pp. 697-711.

NAGY G. Zs. 2015: Csabai Kolbászfesztivál turisztikai hatásainak bemutatása. - Szakdolgozat. 57 p.

SNePEnger, D.-Houser, B.-SNEPEnger, M. 1990: Seasonality of demand. - Annals of Tourism Research 17. 4. pp. 628-630.

SugÁr A. 2000: Időbeli változások egyszerú mutatószámai szezonalitás mellett. - In: HunYADi L. (szerk.): Fél évszázad a statisztika szolgálatában: Tanulmánykötet Köves Pál tiszteletére. KSH, Budapest. pp. 77-88.

SulyoK J.-Kiss K. 2006: A magyarországi turizmus szezonalitása, 2000-2004. - Turizmus Bulletin 10. 1. pp 57-69.

SulyoK J.-Mester T. 2014: A magyarországi turizmus szezonalitása - A kereskedelmi szálláshelyek vendégforgalma. - Turizmus Bulletin 16. 3-4. pp. 85-92.

SutCliffe, C. M. S.-Sinclair, T. 1980: The measurement of seasonality within the tourist industry: An application to tourism arrivals in Spain. - Applied Economics 12. 4. pp. 429-441.

TERRY, W. 2016: Solving seasonality in tourism? Labour shortages and guest worker programmes in the USA. - Area 48. 1. pp. 111-118.

VÁGi Zs. 2012a: Szezonális étlaptervezés. Március. - Élelmezés 3. 3. p 48.

VÁGI Zs. 2012b: Szezonális étlaptervezés. Április-május. - Élelmezés 3. 4-5. p. 21.

1862/2016. (XII. 27.) Korm. határozat a Sopron-Fertő kiemelt turisztikai fejlesztési térség meghatározásáról és a térségben megvalósítandó egyes fejlesztések megvalósításához szükséges források biztosításáról. 